\title{
France rings changes in telecoms efforts
}

[PARIS] France is embarking on a major reorganization of its research in telecommunications, currently carried out mainly by the Centre National d'Études des Télécommunications (CNET), part of the state-owned company France Télécom.

The reforms include the creation of a national federation - the National Network for Telecommunications (RNRT) - intended to coordinate research carried out by France Télécom, which is soon to be privatized, and by public research organizations. There will also be an injection of FFr1.3 billion (US $\$ 230$ million) in government funding over five years into a new research programme linking private companies and public research laboratories.

The reorganization has been prompted by the planned privatization. Until now, CNET has operated almost as a public research organization, serving not only France Télécom but also the entire telecommunications industry, including major manufacturers such as Alcatel-Alsthom. CNET's staff of more than 4,000 makes it the biggest telecommunications research centre in Europe.

The privatization presented a dilemma. Letting CNET stay with France Télécom would have left virtually no public research on telecommunications in France, denying other telecommunications companies a public research base. But transforming CNET into a separate public research body is seen as politically unacceptable.

François Fillon, the telecommunications minister, and François d'Aubert, secretary of state for research, have agreed on a compromise. CNET will remain with France Télécom, while public research will be boosted through a five-year programme intended to encourage research institutions - including the Centre National de la Recherche Scientifique (CNRS) and universities - to move into telecommu- nications research.

CNET is also likely eventually to be reorganized. France Télécom does not make telecommunications components, and is therefore likely to shed its integrated-circuit laboratory at Meylan near Grenoble, and its opto-electronics laboratory at Bagneux, south of Paris. The two centres are already in limbo while the government explores solutions; these include linking Bagneux to AlcatelAlsthom, and Meylan to SGS Thomson, according to one observer. Another possibility would be to create joint units between CNET and public research organizations.

The rebuilding of public research will in practice be carried out by bringing together public research organizations and CNET within the new RNRT. The RNRT will be managed by a steering committee chaired by JeanPierre Noblanc, the director of CEA-Industries, the technology transfer arm of the atomic energy commission, CEA. It will advise the government on research goals and propose projects within the new programme.

The committee's recommendation for projects will be translated into calls for proposals, issued by the ministry of telecommunica-

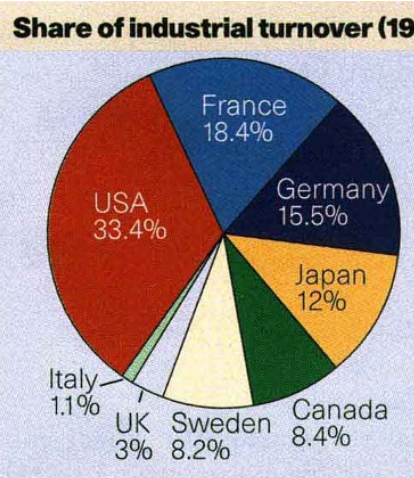

tions and ANVAR, the national agency for technology transfer, which will provide FFrl billion of new funding over five years for industrial research projects.

The science ministry will commit a further FFr300 million for fundamental research. Projects must involve both a private company and a public research body, and grant recipients will be required at least to match the state contributions. As a result, the government estimates that total funding for the programme will amount to FFr4 billion, a figure judged optimistic by many observers.

The role of the steering committee in proposing research projects will be critical to ensuring that the research funded by the programme corresponds to strategic needs, according to Gilles Kahn, scientific director of the national computing agency, INRIA, and co-author of the report on which the government's plans are based. Otherwise, there is a risk that researchers will simply relabel their existing research - on solid-state physics, for example - as telecommunications research to qualify for funding. Scientists are old hands at such tricks, says one observer.

DeclanButler \& Robert Thiend

Crossed lines: Europe's share of telecommunications research lags that of its market presence

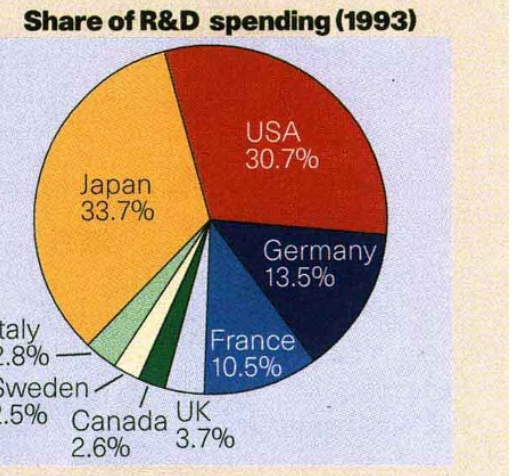

\section{Britain will meet election commitment to rejoin Unesco}

[PARIS] Britain's new Labour government has announced that it plans to meet its preelection promise to rejoin the United Nations Educational, Scientific and Cultural Organization (Unesco). Britain left the organization in 1984 along with the United States, complaining of mismanagement and anti-Western bias.

The UK subscription of around $\mathfrak{E} 11$ million annually will be a welcome addition to Unesco's annual budget of around $\$ 250$ million. But, according to one Unesco official, the greater significance of the United Kingdom's return will be to end what he describes as the "Anglo-Saxon cultural and linguistic absence" of the past decade. The biggest loss to Unesco from the US and UK withdrawal, he says, has been the absence of the "two most important scientific and educational communities in the world".

A spokesperson for the UK Ministry of International Development says that the government is to rejoin because it is satisfied that Unesco has sufficiently reformed itself over the past 13 years, that it shares Unesco's ideals, and that it feels Britain can play a useful role in the organization.

The biggest change in Unesco science programmes over the past decade, claims one Unesco official, is the increased participation of scientific nongovernmental organizations. "People now look on Unesco as a respectable and responsive partner," he says. But critics still maintain that Unesco's science programmes remain weak (see Nature 385, 286; 1997).
President Bill Clinton has also indicated his desire to rejoin Unesco (see Nature 377, 569; 1995). But this has been prevented primarily because of the reluctance of the Republican majority in Congress to pay the \$65-million annual subscription.

A State Department official says that the United States will seriously consider rejoining if the administration and Congress reach agreement on the repayment of US debts to the United Nations in present negotiations. Putting US funding of the UN on "a sound financial footing" is a prerequisite for rejoining Unesco, he says. The agreement reached last week on the balancing of the US budget by 2002 has removed one obstacle to the negotiations.

Declan Butler 